\title{
Effects of Elevated Atmospheric Carbon Dioxide on the Vineyard System of Vitis vinifera: A Review
}

\author{
Molly E. Clemens, ${ }^{1 *}$ Alessandra Zuniga, ${ }^{1}$ and Walter Oechel $^{2,3}$
}

\begin{abstract}
Global atmospheric carbon dioxide concentrations will continue increasing throughout the next century, with profound effects on agriculture. The literature concerning the effects of climate change on viticulture has largely focused on the isolated effects of variables such as temperature and soil water deficit. Likewise, the research on the effects of elevated atmospheric $\mathrm{CO}_{2}$ on grapevines is stunted at the categorical level, chiefly because of the difficulty of experimentally controlling the gaseous environment in situ for the years necessary to replicate the vineyard system in a future climate condition. Despite numerous studies on the short-term influence of environmental and cultural factors on grapevine development at elevated $\mathrm{CO}_{2}$, the long-term effects remain poorly understood. The lack of field based elevated $\mathrm{CO}_{2}$ experiments in the United States is an added challenge to predicting viticultural changes, particularly in California. This review focuses on the systemic effect of atmospheric $\mathrm{CO}_{2}$ on Vitis vinifera, synthesizing physiological, phenological, and plant-pest interactions. Major findings from this synthesis inform of a predicted increase in pest pressure, advanced phenological timing, transient increase in water use efficiency for grapevine, and changes in grape berry chemistry. While water use efficiency is highly desirable, the prediction for current winegrape growing regions is a transient increase in water use efficiency subsequently limited by a lack of available soil water. Grapevine is influenced by the negative synergistic effects of heat, drought, and elevated $\mathrm{CO}_{2}$, which will alter cultural practices including harvest and pest and disease control, with downstream effects on winemaking. Several options for adaptation are discussed including leaf removal, planting alternative varieties, and selective breeding of new varieties.
\end{abstract}

Key words: carbon storage, climate change, elevated $\mathrm{CO}_{2}$, phenology, physiology, viticultural impact, water use, yield

Rising atmospheric carbon dioxide levels are well documented by the International Panels on Climate Change, and $\mathrm{CO}_{2}$ is expected to reach levels between 530 and $720 \mathrm{mg} / \mathrm{L}$ by the year 2100 according to intermediate scenarios (IPCC 2014). The last time Earth experienced levels of $\mathrm{CO}_{2}$ consistently above $400 \mathrm{mg} / \mathrm{L}$ was the early Miocene era, $\sim 23$ million years ago (Pearson and Palmer 2000). The earliest agriculture was cultivated between 23,000 and 12,000 years ago (Weiss

\footnotetext{
${ }^{1}$ San Diego State University and University of California Davis Joint Doctoral Program in Ecology, San Diego, CA 92182; ${ }^{2}$ Global Change Research Group, Department of Biology, San Diego State University, San Diego, CA 92182; and ${ }^{3}$ Department of Geography, University of Exeter, Exeter, EX4 4RJ UK.

*Corresponding author (mclemens@ucdavis.edu)

Acknowledgments: The authors thank Susanne Tittmann for her time in discussing the GrapeFACE project at Geisenheim, Germany. The authors also thank Stefano Poni for the indepth discussion of leaf removal as a climate change mitigation strategy. The authors would also like to recognize that preliminary ideas and perspectives were formulated while working in the Experimental Vineyard at San Diego State University's Santa Margarita Ecological Reserve. The authors had financial support from the Joint Doctoral Program in Ecology at SDSU with UC Davis and from NOAA Educational Partnership Program/ Minority Serving Institutions award number NA16SEC4810008. The authors did not have any industry interest conflicting with this work.

Manuscript submitted June 2021, revised Oct 2021, accepted Oct 2021

Copyright $(\mathcal{C} 2022$ by the American Society for Enology and Viticulture. All rights reserved.

By downloading and/or receiving this article, you agree to the Disclaimer of Warranties and Liability. The full statement of the Disclaimers is available at http://www.ajevonline.org/content/proprietary-rights-notice-ajev-online. If you do not agree to the Disclaimers, do not download and/or accept this article. doi: 10.5344/ajev.2021.21029
}

et al. 2004), with the earliest grape domestication estimated between 6000 and 9000 years ago (Terral et al. 2010). Grapevine has historically been sensitive to changes in climate, including the "Little Ice Age" in Europe (Mariani et al. 2018) and the more recent heat waves of the 21st century (Galat Giorgi et al. 2019, Venios et al. 2020, Bertamini et al. 2021).

While grapevine is typically cultivated in regions with wet winters and dry summers, increasing events of severe water stress will impede growth and reduce quality and yield in grapevine under climate change (Chaves et al. 2010, Mosedale et al. 2016, Scholasch and Rienth 2019, Morales-Castilla et al. 2020). Mean climate projections underestimate the effect of climate change on grapevine, in particular the effect of extreme temperature spikes or drops in areas growing premier winegrapes, currently characterized by few days with extreme heat or cold (White et al. 2006, Parker et al. 2020). While vines in Mediterranean areas will have to adapt to a more variable climate, elevated $\mathrm{CO}_{2}$ will compound the effects of heat and drought stress at a global scale, affecting the quality and quantity of grapevine yield (Jones et al. 2005, Schultz 2010, Mosedale et al. 2016, Van Leeuwen and Darriet 2016, Bertamini et al. 2021). $\mathrm{CO}_{2}$ levels present a relatively novel challenge because they have been increasing at an unprecedented rate since the start of the Industrial Revolution (IPCC 2014).

Winegrapes are one of the most culturally and economically important crops worldwide, with an annual production of 60 million tons of fruit annually, the highest monetary value of fruit crops, and wine being part of the UNESCO intangible cultural heritage of humanity (Vivier and Pretorius 
2002, Owens 2008, Ponti et al. 2018, Delrot et al. 2020, Santos et al. 2020). While wild grapevines can be very resilient to abiotic stress, domesticated winegrapes are far more sensitive; a result of the meticulous conservation of berry phenotype with emphasis on flavor over stress tolerance since $400 \mathrm{BCE}$ (Terral et al. 2010, Mariani et al. 2018). While this careful preservation of grape berry phenotype benefits the culture and industry of winegrape growing, as an ecological system, the vineyard is vulnerable to a changing climate and elevated atmospheric $\mathrm{CO}_{2}$ levels (Jones 2005).

Heat, elevated $\mathrm{CO}_{2}$, and limited water availability are necessary for cultivating quality grapes, however, studies on their interactive effects indicate these will have a negative synergistic effect on grapevine (Lobell et al. 2006, Edwards et al. 2017, Galat Giorgi et al. 2019). The variety-specific responses to these environmental conditions introduces further variability to any study of grapevine response to future climate (Wohlfahrt et al. 2017), while variability in viticultural production is often viewed as undesirable. The varying physiology of cultivars and the long-term perennial nature of grapevine creates a challenging subject for adaptation studies; we expect that any adaptation will be much slower than that of annual crops (Lobell et al. 2006, Venios et al. 2020).

This review synthesizes recent literature published on the direct effects of elevated $\mathrm{CO}_{2}$ on grapevine physiology, as well as the indirect effects on phenology and ecological responses of grapevines, including studies of the interactive effects of climate variables. This synthesis focused on literature specific to grapevine, and in addition, included studies on Arabidopsis to explore relevant hypotheses illustrating mechanisms of carbon dynamics in $\mathrm{C} 3$ plants. Results were compared from the four predominant experimental approaches: growth chambers, greenhouses, open top chambers, and Free Air $\mathrm{CO}_{2}$ Enrichment (FACE), all evaluated for predictive value. Finally, this review concludes by discussing potential research necessary for understanding the future of growing grapevine with elevated $\mathrm{CO}_{2}$ and adaptive viticultural management.

\section{Effects on the Vine and Berry Composition}

Physiology. The physiological advantage of increased atmospheric carbon available for crops such as grapevine must be weighed against other factors likely to co-occur in the context of climate change, including water scarcity and temperature increases (Gray et al. 2016, Faralli et al. 2017). The literature asserts that the ribulose-1,5-bisphosphate carboxylase-oxygenase (rubisco) of $\mathrm{C} 3$ plants, including grapevines, are currently limited by ambient $\mathrm{CO}_{2}$ substrate (Long and Drake 1992, Ainsworth and Rogers 2007), and any increases should stimulate carbon assimilation rates and increase vegetative growth (Bowes 1993) in the absence of other stressors. However, grapevine specific studies provide evidence for down regulation of net photosynthesis as vines acclimate to higher carbon environments (Salazar-Parra et al. 2015, Rangel da Silva et al. 2017). Salazar-Parra et al. (2012) observed a transient increase in maximum photosynthesis in grapevine at elevated $\mathrm{CO}_{2}$, but this effect dissipated over time. A short-term study in a temperature gradient greenhouse at $700 \mathrm{mg} / \mathrm{L} \mathrm{CO}_{2}$ showed grapevine photosynthesis increased around the time of veraison (Arrizabalaga-Arriazu et al. 2020), however, studies of this duration are more reflective of a high dose of carbon enrichment rather than simulating future climate scenarios.

One possible explanation for photosynthetic down regulation, i.e., acclimation, is lowered capacity of the photochemical machinery due to reductions in nitrogen $(\mathrm{N})$ concentrations in the leaf (Luo et al. 1994, Moutinho-Pereira et al. 2009), limiting the activity of the rubisco enzyme. Species that are not $\mathrm{N}$ fixing, such as grapevine, are more likely to experience acclimation in elevated $\mathrm{CO}_{2}$ environments because of limited rubisco content (Ainsworth et al. 2002). The $\mathrm{N}$ dilution effect is well documented in other crop species, therefore in grapevine, $\mathrm{N}$ use efficiency could increase in elevated $\mathrm{CO}_{2}$ environments because rubisco acclimation enables $\mathrm{N}$ to be redistributed for other growth in the vine; FACE experiments, however, documented $\mathrm{N}$ gains lower than predicted (Leaky et al. 2009).

The long-term effect of elevated $\mathrm{CO}_{2}$ on rates of grapevine photosynthesis has been shown to be dependent on other climate factors such as temperature and water availability (Wohlfahrt et al. 2018). Water scarcity, a concomitant climate change variable with elevated $\mathrm{CO}_{2}$, can affect the carbon storage in trunks of vines, as demonstrated in fruit tree orchards, and in turn, drought stress can be partially relieved in elevated $\mathrm{CO}_{2}$ scenarios (Paudel et al. 2018). Three general physiological responses will benefit grapevine in an elevated $\mathrm{CO}_{2}$ climate with limited water availability. These responses start with (1) partial stomatal closure limiting water loss, then a (2) subsequent increase in soil water content as transpiration decreases, and finally (3) an increase of starch storage to provide for drought recovery (Salazar-Parra et al. 2015, Paudel et al. 2018). Acclimation to elevated $\mathrm{CO}_{2}$ will decrease rates of assimilation while starch reserves increase, because the carbon sink may be driving rates of photosynthesis rather than carbon availability driving metabolism ( $\mathrm{Li}$ et al. 2021). Therefore, the widespread observed reduction in stomatal conductance $\left(\mathrm{g}_{\mathrm{s}}\right)$ and density (Rangel da Silva et al. 2017, Kizildeniz et al. 2018) may have a greater effect on grapevine water use efficiency (WUE) from decreasing transpiration rather than increasing carbon assimilation.

In the past 10 years, grapevine physiology research under elevated $\mathrm{CO}_{2}$ has focused on the effects on WUE defined as carbon assimilated per unit of water transpired. Grapevine relies on stomatal aperture to facilitate cooling and $\mathrm{CO}_{2}$ uptake, releasing latent heat as the plant reaches physiological temperature thresholds; however, closure is essential to avoid detrimental water loss, heat damage, and reduced photosynthate production (Martínez-Lüscher et al. 2016a). With higher levels of $\mathrm{CO}_{2}$ in the atmosphere, stomata can facilitate a lower water per $\mathrm{CO}_{2}$ molecular exchange, increasing the leaf level WUE (Figure 1). An early study of grapevine under elevated $\mathrm{CO}_{2}$ treatment for one season found no significant effect on $g_{s}$ and transpiration (Moutinho-Pereira et al. 2009). Subsequently, a study using $650 \mathrm{mg} / \mathrm{L}$ in a similar opentop chamber (OTC) found $\mathrm{g}_{\mathrm{s}}$ and transpiration decreased at elevated $\mathrm{CO}_{2}$ (Edwards et al. 2017). In contrast, at only at 
$500 \mathrm{mg} / \mathrm{L}$, higher $\mathrm{g}_{\mathrm{s}}$ and transpiration rates were observed in grapevines in a consistently elevated $\mathrm{CO}_{2}$ environment for three consecutive seasons (Wohlfahrt et al. 2018). On a morphological level, multiple studies have documented the reduction in stomatal density in several varieties of grapevine (Moutinho-Pereira et al. 2009, Rogiers et al. 2011, Rangel da Silva et al. 2017). Scaling intrinsic WUE to the whole plant level will require documenting changes in microclimate as well as morphology, such as stomatal density and leaf area (Medrano et al. 2015).

WUE predicitions are further complicated by the results of combination studies of elevated temperature, reduced soil water availability, and elevated $\mathrm{CO}_{2}$, which reveal synergistic effects. In an OTC study, combining temperature and $\mathrm{CO}_{2}$ did not result in $\mathrm{g}_{\mathrm{s}}$ being significantly reduced, contrary to results of elevated $\mathrm{CO}_{2}$ alone (Edwards et al. 2017). When latent heat is trapped, overheating subsequently decreases the activity of rubisco activase, for most plants at temperatures higher than $37^{\circ} \mathrm{C}$ (Crafts-Brandner and Salvucci 2000), and in grapevine between 35 and $40^{\circ} \mathrm{C}$, varying by species (Luo et al. 2011, Salazar-Parra et al. 2012). The elevated $\mathrm{CO}_{2}$ and temperature treatments showed an increase in transpiration
(Edwards et al. 2016), and the effects of drought were only temporarily delayed (Rangel da Silva et al. 2017). Temperature and elevated $\mathrm{CO}_{2}$ had an additive effect on plant leaf area for multiple grapevine clones (Arrizabalaga-Arriazu et al. 2020), highlighting that overall higher leaf area without increased WUE could be detrimental for heat stressed vines. Measurements of predawn water potential were more negative in vines at elevated $\mathrm{CO}_{2}$, indicating the demand for soil water availability of vines with increased productivity (Wohlfahrt et al. 2018). Notedly, the production of fine roots was positively affected by an elevated $\mathrm{CO}_{2}$ treatment, which would theoretically increase water absorption of water available (Reddy et al. 2018).

There remain inconsistent predictions of the effects of elevated $\mathrm{CO}_{2}$ on grapevine whole-plant WUE, which seem to be contingent on other factors such as soil water availability, temperature, and variety of grapevine. With the evidence from these studies of elevated $\mathrm{CO}_{2}$ and combination studies of soil water availability and temperature, grapevines most likely will not benefit from a long-term increase in photosynthesis under elevated $\mathrm{CO}_{2}$. The lack of soil water available and biological temperature thresholds for rubisco will limit

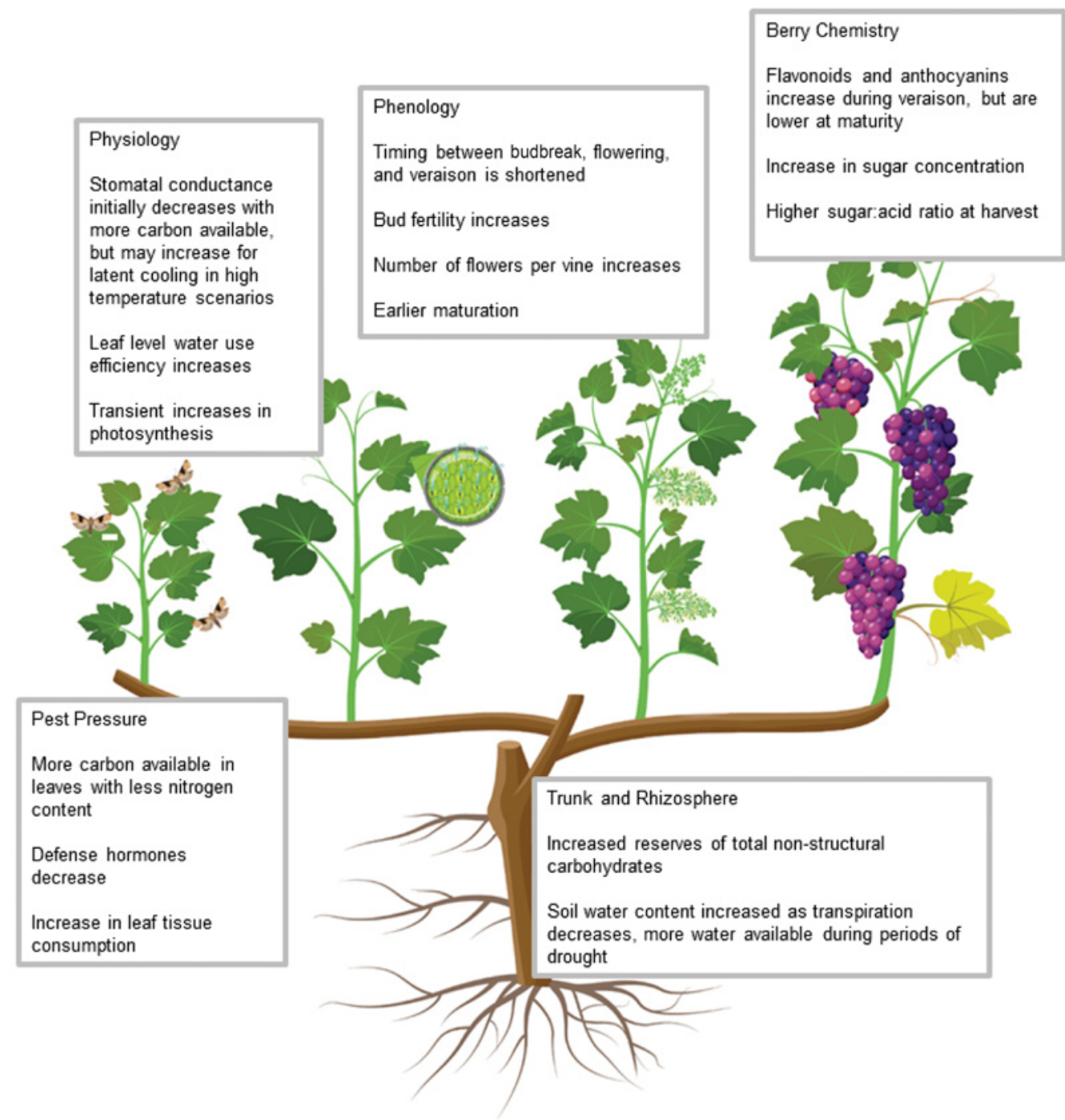

Figure 1 At a biophysiological level, elevated carbon dioxide $\left(\mathrm{CO}_{2}\right)$ affects the production and storage of sugars (total nonstructural carbohydrates) and the balance of growth. Indirect effects of rising $\mathrm{CO}_{2}$ levels catalyze top-down effects of increased carbon:nitrogen (C:N) ratios with subsequent increases in herbivory. Grapevine phenology is a sensitive two-year cycle of growth spurts and acid degradation before harvest, with profound effects on grape berry quality when the timing is shifted. Intrinsic water use efficiency (WUE) at the leaf level increases as stomatal conductance decreases and more carbon is available per water molecule lost. However, WUE at the whole plant level depends on soil water available, which will vary depending on microclimate and future climate conditions. 
the gains in photosynthesis, and more likely the vines will struggle to release latent heat as temperatures rise.

Phenology. Grapevine phenology is categorized into four life cycle stages of periodic development: budbreak, flowering, veraison, and maturation. The grapevine phenological cycle is a two-year process; bud formation occurs in the first year and shoots develop in the second year. Therefore, clusters are significantly affected by the previous year's climate (Vasconcelos et al. 2009). For grapevine grown at elevated $\mathrm{CO}_{2}$, advances in phenology compound significantly over seasons (Edwards et al. 2017). This is likely the result of stored carbon photosynthate from the productive previous year. As a result, it can take several years to observe the effects of elevated $\mathrm{CO}_{2}$ on grapevine phenology (Edwards et al. 2017), which leads to the question of "To what extent does elevated $\mathrm{CO}_{2}$ affect the timing of phenological stages over the longterm?"

Studies of Arabidopsis, another C3 flowering plant, provide insight to the mechanisms of phenological changes observed in grapevine. Excess carbohydrates may act similarly to phytohormones to delay the upregulation of genes involved in flowering time, as well as cell wall invertases in the meristem that downregulate photosynthesis under treatments of elevated $\mathrm{CO}_{2}$, which leads to earlier flowering (Springer and Ward 2007). For grapevine, it is possible that excess photosynthate could trigger early flowering through the transfer of carbohydrates from leaves. One of the most robust findings to support this hypothesis is that growth under elevated $\mathrm{CO}_{2}$ results in increased carbohydrate reserves in plants (Kizildeniz et al. 2021).

The sugars produced by photosynthesis contribute only a fraction of the source of carbon needed for rapid growth and development from budbreak to flowering and sugar accumulation in berries at veraison; the remaining needed for these growth spurts is mobilized from long-term storage of total nonstructural carbohydrates (TNC) in trunks and roots (Zufferey et al. 2012). Over several growing seasons, storage of carbohydrates in the trunk will be affected by elevated $\mathrm{CO}_{2}$ (Lebon et al. 2008) and could therefore contribute to shifts in phenology. In a greenhouse study of fruiting cuttings where sugar accumulation in berries was measured, elevated $\mathrm{CO}_{2}$ increased the rate of ripening correlated with the photosynthetic rate (and was only slightly mediated by UV-B treatments) (Martínez-Lüscher et al. 2015). The effect of elevated $\mathrm{CO}_{2}$ on phenology was greater than the treatment of temperature elevated by $4^{\circ} \mathrm{C}$ (Martínez-Lüscher et al. 2016a). Therefore, an increase in TNCs could be a driver of advances in phenology long term on its own, as well as with concomitant increases in growing season temperatures.

Carbohydrate reserves regulate the growth and differentiation of flowers, which only occurs after the grapevine shoot is resource independent from the rest of the vine (Lebon et al. 2008, Vasconcelos et al. 2009). These findings suggest that with an increase in carbon reserves stored as starch in roots, trunks, and canes, second season shoots may grow faster and achieve independence earlier in the growing season. This could contribute to early flowering as a result of lifted competition for resources between vegetative and reproductive growth. In contrast, long-term studies in grapevine decreasing the leaf-to-fruit ratios (measured as light-exposed leaf area to fruit) decreased essential reserves of the TNC in the roots (Zufferey et al. 2012). The well-known viticultural technique of strategic leaf removal has been shown to delay maturation, highlighting the importance of carbon availability for phenological development (Poni et al. 2006, Parker 2012, Parker et al. 2014).

While the mechanism for phenological shifts in grapevine grown under elevated $\mathrm{CO}_{2}$ is under-studied, these shifts have been quantified using FACE experiments. The combination of elevated $\mathrm{CO}_{2}$ and temperature in OTCs caused an advance in flowering time by three days and veraison by two weeks (Edwards et al. 2016). The effect of elevated $\mathrm{CO}_{2}$ on phenological timing is greatest during the period between fruit set to veraison and this effect increases when combined with a temperature treatment (Martínez-Lüscher et al. 2016b, Arrizabalaga-Arriazu et al. 2020). During fruit set, elevated $\mathrm{CO}_{2}$ treatments with and without temperature treatments increased total soluble solids (TSS; hastening maturation), as well as decreased anthocyanins and malic acid concentration, which would contribute to an earlier veraison and harvest (Salazar-Parra et al. 2010). However, the effect of high temperature may have a greater effect on this phenological period (Arrizabalaga-Arriazu et al. 2020).

The quality of fruit harvested is the utmost concern when considering advanced phenology. Grapevines vulnerable to frost damage will suffer from early budbreak, with subsequent losses in yield (Fraga et al. 2016). One consequence of increased shoot vigor at elevated $\mathrm{CO}_{2}$ is the expected increase in bud fertility, which will likely increase the number of flowers per vine (Figure 1) (Bindi et al. 2001, Delrot et al. 2020). Changes in cluster density and phenological timing affect the carefully articulated annual harvest. Unbalanced sugar-toacid ratios resulting from early harvest decrease the quality of grapes and wine produced, which is discussed further in the "Berry and Wine Chemistry" section below (Jones et al. 2005, Jones 2013). Shifting the lifecycle of grapevine will have a global effect on winegrape production.

Berry and wine chemistry. Fruit composition is a major area of concern for growers and winemakers alike, especially aromatic compounds. The changes in pest interactions, physiology, and timing of veraison in response to elevated $\mathrm{CO}_{2}$ will collectively affect the resulting grape and wine quality (Ollat et al. 2017). For successful wines, in the grape berry there is a balance of acid and sugar at harvest. Increasing atmospheric carbon available affects the balance as ripening advances and sugar accumulation is accelerated (Martínez de Toda et al. 2014). Flavonoids and anthocyanins are important for the flavor, color, and mouthfeel of wine. The molecular analysis from the original Italian FACE experiments showed increases in total flavonoids, total anthocyanins, and total nonanthocyanin flavonoids in the wine produced with carbon enriched grapes grown at $700 \mathrm{mg} / \mathrm{L}$ (Bindi et al. 2001), which typically would affect the color and mouthfeel of wine. Interestingly, a subsequent experiment using $500 \mathrm{mg} / \mathrm{L} \mathrm{CO}_{2}$ 
OTCs determined there were significant increases in ethyl 2-methylbutyrate (apple), isoamyl acetate (burnt), ethyl hexanoate (apple, pineapple), ethyl octanoate (fruit/fat), butyric acid (rancid), and isovaleric acid (rancid) concentrations and a significant decrease in ethyl acetate (fruity) concentration in wines produced from enriched $\mathrm{CO}_{2}$ grapes after one year (Gonçalves et al. 2008), which contribute to the balance of floral and fruity characteristics in wines (Francis 2012). In the second year, they found lower methionol (raw potato), 1-octanol (alcohol), and 4-ethylguaiacol (smoke), and higher ethyl lactate (butter) and linalool (floral) concentrations, although these changes in berry chemistry did not appear to significantly affect the quality of wine produced (Gonçalves et al. 2008). These results agree with early studies led by Bindi et al. (2001) that did not find significant effects on the quality of wine produced from grapes grown at elevated $\mathrm{CO}_{2}$ (Table 1).

Although the changes observed in compounds contributing to flavor have been noted as so far insignificant for quality, a major concern for winemakers is the increase in alcohol content resulting from an increase in sugar concentrations in berries, as a result of higher $\mathrm{CO}_{2}$ concentrations (Van Leeuwen and Darriet 2016, Teslić et al. 2018, Delrot et al. 2020, Ubeda et al. 2020). In the past, winemakers have added sugar to the fermentation to increase the final alcohol percentage (chaptalization where legal), depending on legal regulations for winemaking. However, in recent years winemakers have begun removing sugar through processes like reverse osmosis to prevent alcohol levels from rising (Christmann et al. 2017, Delrot et al. 2020). Overall, elevated $\mathrm{CO}_{2}$ is altering the balance of sugar accumulation, the levels of tartaric and malic acids in berries and wine, and the effect on wine quality continues to be investigated (Table 1) (Gonçalves et al. 2008, Pons et al. 2017).

The most recent FACE studies on grapes continue to evaluate the berry chemistry and quality developing over years of exposure to elevated $\mathrm{CO}_{2}$. The GrapeFACE in Germany analyzed must from grapes after pressing and did not find a significant increase in sugar content from conditions of carbon enrichment (Wohlfahrt et al. 2018). The Gonçalves et al. (2008) study also concluded that changes in water availability and heat stress could change their predictions in wine quality. We should expect that with the shifts in phenology and physiological changes to berries, early harvest will affect the quality of grapes in terms of reaching maturation too quickly (Martínez-Lüscher et al. 2016b). Viticulturists could also anticipate altered physiological demands to have longterm effects on berry quality (Pons et al. 2017).

Pest and disease pressure. In contrast to the ecological pressures discussed above, the rates of some fungal infections may be reduced in elevated $\mathrm{CO}_{2}$ scenarios. With higher carbon allocation to roots, grapevine mycorrhizal colonization may be promoted by elevated $\mathrm{CO}_{2}$ (Torres et al. 2018), which has been shown to protect grapevine against the nematode Xiphinema index by stimulating defense gene response (Hao et al. 2012). A study of elevated $\mathrm{CO}_{2}$ on several varieties of grapevine seedlings showed a reduced severity of the infection of Xanthomonas campestris pv. viticola, a vector of bacterial canker in immature grapevine (Table 1) (Conceição et al. 2017). This may be the result of lower $g_{s}$; with stomatal aperture reduced, there is less opportunity for bacteria to invade the leaf pores (Conceição et al. 2017, Kizildeniz et al. 2018). Also, researchers recorded a reduced instance and severity of powdery mildew infection in cv. Barbera, at elevated $\mathrm{CO}_{2}$ (Table 1) (Pugliese et al. 2010). The Geisenheim GrapeFACE site recorded changes in the bunch architecture but did not see an increase in the frequency of Botrytis cinerea (botrytis bunch rot, a necrotrophic fungus) occurrence (Wohlfahrt et al. 2018).

Changes in leaf chemistry phenotype, specifically carbon content (e.g., higher soluble carbohydrates due to higher $\mathrm{CO}_{2}$ levels), will increase the pressure of grapevine pests in future climates. Increasing available $\mathrm{CO}_{2}$, without a concomitant increase in nutrient levels in the soil, leads to an increase in carbon:nitrogen $(\mathrm{C}: \mathrm{N})$ ratios in leaves (Figure 1) (Hunter 2001, Ainsworth and Long 2004, Moutinho-Pereira et al. 2009, Arrizabalaga-Arriazu et al. 2020, Kizildeniz et al. 2021). Insects consume at higher rates when $\mathrm{N}$ has been diluted to meet their $\mathrm{N}$ intake needs, and chewing insect pests will generally eat more leaf tissue in elevated $\mathrm{CO}_{2}$ scenarios (Hunter 2001). Elevated $\mathrm{CO}_{2}$ increased individual survival rates and increased the fecundity of female mealybugs, which eat the phloem of grapevine damaging the temporal and perennial plant tissue (Bordeu et al. 2012, Schulze-Sylvester and Reineke 2019, Schulze-Sylvester et al. 2021). The European grapevine moth, Lobesia botrana, is a major problem for European vineyards, affecting both the berries and flowers of grapevines; it has already invaded North and South American vineyards (Reineke and Selim 2019). L. botrana is also responsible for spreading Ochratoxin A-producing $A s$ pergillus fungi, which typically spikes in occurrence during hotter and drier years (Mondani et al. 2020). At higher temperatures simulating future climate conditions, $L$. botrana female growth rate and pupal mass increased (Iltis et al. 2018), while researchers found a down regulation of expression of ethylene-responsive factors, which suggests grapevines can become more vulnerable to herbivory or abiotic stress under future climate change because these are the major stress and defense response factors (Reineke and Selim 2019).

A comprehensive study of soil and elevated $\mathrm{CO}_{2}$ showed the decomposition pathway is altered by the carbon-, nitrogen-, and phosphorus-acquiring enzymes in the soil with a significant increase in nematode density (Thakur et al. 2019). More than 4000 plant-parasitic nematodes exist, posing a well-known global issue for grapevine by reducing total crop production from 8.8 to $14.6 \%$; one of the worst threats from the nematode $X$. index is grapevine leaf roll virus (GLRV) (Andret-Link et al. 2017). Under elevated $\mathrm{CO}_{2}$ conditions, if ethylene is suppressed and salicylic acid is increased, it is likely that grapevine will struggle with an increase in pest and disease vectors such as nematodes and fungi (Reineke and Selim 2019). Grapevines largely rely on human intervention for defense against pests and diseases (Pertot et al. 2017), and this reliance could increase in future climates. Consider the grapevine "immune system" as weakened in terms of chemical 
Table 1 Studies of carbon enrichment with grapevine using temperature growth chambers (GC), greenhouse (GH), temperature gradient greenhouses (TGG), open top chambers (OTC), and Free Air Carbon Enrichment (FACE) with significant findings are summarized here. The contrast in results for photosynthetic response is likely due to the duration of the studies and the material used (fruiting cuttings for the Salazar-Parra et al. [2015] study versus field grown vines for Wohlfahrt et al. [2017, 2018]). Photosynthesis $\left(A_{n e t}\right)$ increased in response to elevated $\mathrm{CO}_{2}$ in all these studies. However, the downstream effect on phenology has unclear results, as the Edwards FACE studies $(2016,2017)$ showed a significant effect on the timing of veraison, while the more recent temperature gradient greenhouse study by Arrizabalaga-Arriazu et al. (2020) did not. Few studies document long-term effects on phenology, and there have been no studies in the United States using FACE.

\begin{tabular}{|c|c|c|c|c|}
\hline Citation & $\begin{array}{c}\mathrm{eCO}_{2} \text { levels } \\
(\mathrm{mg} / \mathrm{L})\end{array}$ & Method & Notable results ${ }^{a}$ & Location \\
\hline Bindi et al. 2001 & 550 and 700 & FACE & $\begin{array}{l}\text { Vegetative growth } \\
\text { No significant effect on wine quality } \\
\text { (20-year-old vines) }\end{array}$ & Italy \\
\hline Gonçalves et al. 2008 & 500 & OTC & No significant effect on wine quality & Portugal \\
\hline Moutinho-Pereira et al. 2009 & 500 & OTC & $\begin{array}{l}\text { Photosynthesis }\left(\mathrm{A}_{\text {net }}\right) \\
\text { Intrinsic water use efficiency }\left(\mathrm{A} / \mathrm{g}_{\mathrm{s}}\right) \\
\text { Leaf thickness } \\
\mathrm{Mg} \text { concentration } \\
\mathrm{C} / \mathrm{N}, \mathrm{K} / \mathrm{N} \text {, and } \mathrm{Mg} / \mathrm{N} \text { ratios } \\
\text { Stomatal density and } \mathrm{N} \text { concentration }\end{array}$ & Portugal \\
\hline Pugliese et al. 2010 & 800 & GC & $\begin{array}{l}\text { Chlorophyll content } \\
\text { Instance and severity of powdery mildew increased for } \\
\text { cv. Moscato } \\
\text { Instance and severity of powdery mildew increased for } \\
\text { cv. Barbera }\end{array}$ & Italy \\
\hline Salazar-Parra et al. 2012 & 700 & $\mathrm{GH}$ & $\begin{array}{l}\text { Reactive oxygen species } \\
\text { No significant change in photosynthetic pigments }\end{array}$ & Spain \\
\hline Salazar-Parra et al. 2015 & 700 & TGG & $\begin{array}{l}\text { No effect on photosynthetic rates } \\
\text { Stomatal conductance and transpiration at } 20 \text { days }\end{array}$ & Spain \\
\hline Martínez-Lüscher et al. 2015 & 700 & $\mathrm{GH}$ & $\begin{array}{l}\text { Photosynthesis }\left(A_{\text {net }}\right) \\
\text { Dark respiration } \\
\text { Photorespiration } \\
\text { Chlorophyll a and b content } \\
\text { Ripening rates }\end{array}$ & Spain \\
\hline Martínez-Lüscher et al. 2016a & 700 & TGG & $\begin{array}{l}\text { Advanced phenology with and without combination of } \\
\text { elevated temperature, with cultivar specific response }\end{array}$ & Spain \\
\hline Edwards et al. 2016, 2017 & 650 & OTC & $\begin{array}{l}\text { Anthesis and veraison advanced in the third season } \\
\text { Light saturated assimilation }\left(\mathrm{A}_{\text {sat }}\right)\end{array}$ & Australia \\
\hline Rangel da Silva et al. 2017 & 800 & GC & $\begin{array}{l}18 \% \text { reduction in leaf nitrogen content } \\
25 \% \text { reduction in stomatal density } \\
\text { Generally increased drought tolerance }\end{array}$ & USA \\
\hline Conceição et al. 2017 & 770 & GC & $\begin{array}{l}\text { Decreased infection of bacterial disease of } \\
\text { Xanthomonas campestris pv viticola }\end{array}$ & Brazil \\
\hline Wohlfahrt et al. 2017, 2018 & $\begin{array}{l}480-500 \\
(+20 \% \\
\text { ambient })\end{array}$ & FACE & $\begin{array}{l}\text { Photosynthesis }\left(A_{\text {net }}\right) \\
\text { Intrinsic water use efficiency }\left(A / g_{s}\right) \text { predawn leaf water } \\
\text { potential } \\
\text { Bunch compactness, weight, and length } \\
\text { Ethylene signals and ethylene responsive factors }\end{array}$ & Germany \\
\hline Kizildeniz et al. 2018 & 700 & TGG & $\begin{array}{l}\text { gs, with additive effect of temperature and drought } \\
\text { Stimulated more vegetative than reproductive growth } \\
\text { WUE increases did not compensate for water stress }\end{array}$ & Spain \\
\hline Reineke and Selim 2019 & 500 & FACE & $\begin{array}{l}\text { Ethylene signaling hormones } \\
\text { Defensive compounds, including salicylic acid } \\
\text { Vulnerability to moth L. botrana }\end{array}$ & Germany \\
\hline $\begin{array}{l}\text { Arrizabalaga-Arriazu et al. } \\
2020\end{array}$ & 700 & TGG & $\begin{array}{l}\text { Phenology and cluster traits not significantly affected } \\
\text { Increased leaf area at maturity } \\
\text { Photosynthesis }\left(A_{n e t}\right) \\
\text { Stomatal conductance }\left(g_{s}\right)\end{array}$ & Spain \\
\hline
\end{tabular}

a indicates increase; indicates decrease; - indicated no change; C, Calcium; N, Nitrogen; K, Potassium; Mg, Magnesium. 
defense, but some altered carbon dynamics under elevated $\mathrm{CO}_{2}$ may be beneficial for reducing severity of pest pressure.

\section{Discussion}

An anticipated management solution to phenological shifts is planting later-ripening and stress-tolerant alternative varieties. Governmental response to climate change will determine the actions European growers are allowed to take to adapt to climate change, considering the current trials of alternative varieties planted in small diversity blocks in France as a positive example (Morales-Castilla et al. 2020). Ancient varieties being tested in temperature gradient greenhouses in Spain for response to combination stresses of drought, heat, and elevated $\mathrm{CO}_{2}$ showed greater resiliency to stress and did not shift phenological timing, although this was a short-term experiment (Antolín et al. 2021, Goicoechea et al. 2021). In some cases, alternative varieties may be hybrid crosses between existing cultivars and later ripening varieties. However, hypothetical crosses between very late-ripening varieties were modelled and still struggle to be late-ripening enough to endure the predicted 23-day shift and potential increase of $7^{\circ} \mathrm{C}$ expected by the end of this century for major winegrape growing areas (Duchêne et al. 2010). Alternative varieties can be identified by enological and ecological principals that make them suitable candidates for replacing existing cultivars, such as flavor profile and ability to survive long-term through stressful climate change conditions (Antolín et al. 2021, Goicoechea et al. 2021). The challenge of adapting new varieties is highlighted by current popular varieties struggling with increases in growing season temperatures (Jones 2021), however a combination of diversity block trials and greenhouse experiments will guide predictions of the best alternatives (Wolkovich et al. 2018).

Our present knowledge of grapevine climate niches is limited relative to the vast diversity of cultivars (Duchêne et al. 2010). With California as an example, there are many potential late-ripening varieties suitable as alternatives to early ripening Chardonnay that have yet to be tested in diversity blocks (Wolkovich et al. 2018). Even clones can have a varied response to climate change variables (Arrizabalaga-Arriazu et al. 2020). Varieties with heat and drought tolerance traits are a starting point for elevated $\mathrm{CO}_{2}$ studies, as we expand from understanding the mechanisms of change into exploring mitigation strategies. Exploring the vast diversity of grapevine using diversity plots is a straightforward ecological approach, which could be enhanced by evaluating the success of plants under several biotic and abiotic stresses predicted for the future.

Many studies on the effects of leaf removal suggest that manipulating canopy cover is an effective way to mitigate phenological shifts caused by climate change (Parker 2012, Martínez de Toda et al. 2014). Leaf removal at prebloom positively influences cell division in inflorescence by reducing sugar transport and decreasing flower fertility, which mitigates cluster compactness (Lebon et al. 2008, VanderWeide et al. 2021). Not only can leaf removal aid in delaying phenology, but other positive effects also include increasing the acid-to-sugar ratio at harvest, increasing production of antho- cyanins and flavonoids, and decreasing incidence of bunch rot disease (Kliewer and Smart 1989, Martínez de Toda et al. 2014, VanderWeide et al. 2021).

Ecologists generally study a system's responses and interactions, and viticulturists need this system perspective for the challenges presented by climate change. Our understanding of the effects of elevated $\mathrm{CO}_{2}$ on the vineyard system is profoundly complicated by the interactive effects of other biotic and abiotic stressors. From an ecological perspective, long-term FACE studies are the most realistic predictors of response to elevated $\mathrm{CO}_{2}$. Advocating for long-term agroecological studies is necessary to evaluate the top-down and bottom-up effects of higher carbon availability on pest/disease interactions, grapevine growth and phenology dynamics, and the resulting quality of wine produced.

Grapevine physiology will be affected by elevated $\mathrm{CO}_{2}$, increasing temperatures, and extreme heat events during the growing season (De Cortázar-Atauri et al. 2017, Ugaglia et al. 2019). FACE experiments highlight the necessity of water availability for grapevines to take advantage of increased $\mathrm{CO}_{2}$ for productivity. Soil water availability affects the opening of stomata, and in the case of GrapeFACE, the vines had increased $\mathrm{g}_{\mathrm{s}}$ with more $\mathrm{CO}_{2}$ available (Wohlfahrt et al. 2018). Grapevines may need more water under future climate conditions of elevated $\mathrm{CO}_{2}$ and temperature, while precipitation is expected to decrease in most of the winegrowing regions of the world. Desiccation threatens vines through water loss from latent cooling under elevated temperature, resulting in higher cumulative water loss even when operating at higher WUE. The modulating response of stomata documented across literature is dependent on the soil water availability and temperature regimes (Arrizabalaga-Arriazu et al. 2020). In this synthesis, the varying levels of $\mathrm{CO}_{2}$, ambient temperatures, and duration of these experiments could have contributed to these contrasting results of stomatal behavior, as well as the conditions of the chambers and greenhouses, versus FACE infrastructure.

Physiological response to abiotic stresses in future climate change conditions is likely to weaken grapevine, creating a vulnerability for biotic stresses such as pests. Overall, chewing pest pressure is anticipated to increase as $\mathrm{CO}_{2}$ and temperature increase (Reineke and Selim 2019). It is unknown whether pest pressure can be compensated by the predicted increase in foliar growth and the effect of lower nutrient density on the populations of pests. The growing season for grapes may require drastic changes in viticultural practices to manage pests, alleviate heat and drought stress, and predict harvest dates. Fungal infections are responsible for the majority of crop damage, therefore, it is critical to clarify if fungal infection will decrease in the future for predictions of grapevine yield.

One of the biggest challenges for grapegrowers will be the shifts in phenological timing with the potential for frost at early budbreak, alterations in cluster formation and density, and compromising harvest with early maturation. Many of the short-term experiments described here did not find significant effects on phenology and yield, while long-term studies account for acclimation and compounding effects of seasonal 
exposure to elevated $\mathrm{CO}_{2}$. Predictions of overall vineyard response to climate change are more accurate when experiments are field based, multiseasonal, and combine the variables of water availability and temperature.

\section{Conclusions}

A combination of the effects of pest pressure, phenology, and physiology predict a much different future environment for growing grapes. Elevated $\mathrm{CO}_{2}$ is a pervasive threat to the vineyard system because it fuels undesirable growth. Grapevine will sustain the effects of elevated $\mathrm{CO}_{2}$ for generations as a perennial crop with a rich memory and sensitive expression of climate. We can strengthen the vineyard system by introducing more diverse cultivars, with an ideal candidate fitting the profile of heat and drought tolerant, late ripening, and with strong pest resistance.

\section{Literature Cited}

Ainsworth EA and Long SP. 2004. What have we learned from 15 years of free-air $\mathrm{CO}_{2}$ enrichment (FACE)? A meta-analytic review of the responses of photosynthesis, canopy properties and plant production to rising $\mathrm{CO}_{2}$. New Phytol 165:351-372.

Ainsworth EA and Rogers A. 2007. The response of photosynthesis and stomatal conductance to rising $\left[\mathrm{CO}_{2}\right]$ : Mechanisms and environmental interactions. Plant Cell Environ 3:258-270.

Ainsworth EA et al. 2002. A meta-analysis of elevated $\mathrm{CO}_{2}$ effects on soybean (Glycine max) physiology, growth and yield. Glob Chang Biol 8:695-709.

Andret-Link P, Marmonier A, Belval L, Hleibieh K, Ritzenthaler C and Demangeat G. 2017. Ectoparasitic nematode vectors of grapevine viruses. In Grapevine Viruses: Molecular Biology, Diagnostics and Management. Meng et al. (eds.), pp. 505-529. Springer, Cham.

Antolín MC, Toledo M, Pascual I, Irigoyen JJ and Goicoechea N. 2021. The exploitation of local Vitis vinifera L. biodiversity as a valuable tool to cope with climate change maintaining berry quality. Plants 10:71.

Arrizabalaga-Arriazu M, Morales F, Irigoyen JJ, Hilbert G and Pascual I. 2020. Growth performance and carbon partitioning of grapevine Tempranillo clones under simulated climate change scenarios: Elevated $\mathrm{CO}_{2}$ and temperature. J Plant Physiol:153-226.

Bertamini M, Faralli M, Varotto C, Grando MS and Cappellin L. 2021. Leaf monoterpene emission limits photosynthetic downregulation under heat stress in field-grown grapevine. Plants 10:181.

Bindi M, Fibbi L and Miglietta F. 2001. Free Air $\mathrm{CO}_{2}$ Enrichment (FACE) of grapevine (Vitis vinifera L.): II. Growth and quality of grape and wine in response to elevated $\mathrm{CO}_{2}$ concentrations. Eur $\mathrm{J}$ Agron 14:145-155.

Bordeu E, Troncoso DO and Zaviezo T. 2012. Influence of mealybug (Pseudococcus spp.)-infested bunches on wine quality in Carmenere and Chardonnay grapes. Int J Food Sci Tech 47:232-239.

Bowes G. 1993. Facing the inevitable - plants and increasing atmospheric $\mathrm{CO}_{2}$. Annu Rev Plant Physiol 44:309-332.

Chaves MM, Zarrouk O, Francisco R, Costa JM, Santos T, Regalado AP, Rodrigues ML and Lopes CM. 2010. Grapevine under deficit irrigation: hints from physiological and molecular data. Ann Bot 105:661-676.

Christmann M, Schmitt M and Pasch L. 2017. Managing climate change: Optimising cool climate wine styles: Impact of dramatic climatic change on traditional viticultural and oenological practices. Wine Viti J 32:20-22.
Conceição JL, Angelotti F, Peixoto AR and Ghini R. 2017. Infection by Xanthomonas campestris pv. viticola under temperature increase and carbon dioxide concentrations. Com Sci 8:214-20.

Crafts-Brandner SJ and Salvucci ME. 2000. Rubisco activase constrains the photosynthetic potential of leaves at high temperature and $\mathrm{CO}_{2}$. Proc Natl Acad Sci USA 97:13430-13435.

De Cortázar-Atauri IG, Duchêne E, Destrac-Irvine A, Barbeau G, De Rességuier L, Lacombe T, Parker A, Saurin N and Van Leeuwen C. 2017. Grapevine phenology in France: from past observations to future evolutions in the context of climate change. OENO One 51:115-126.

Delrot $\mathrm{S}$ et al. 2020. Genetic and genomic approaches for adaptation of grapevine to climate change. In Genomic Designing of ClimateSmart Fruit Crops. Kole C (ed.), pp. 157-270. Springer, Cham.

Duchêne E, Huard F, Dumas V, Schneider C and Merdinoglu D. 2010. The challenge of adapting grapevine varieties to climate change. Clim Res 41:193-204.

Edwards EJ, Unwin DJ, Sommer KJ, Downey MO and Mollah M. 2016. The response of commercially managed, field grown, grapevines (Vitis vinifera L.) to a simulated future climate consisting of elevated $\mathrm{CO}_{2}$ in combination with elevated air temperature. Acta Hortic 1115:103-110.

Edwards E, Unwin D, Kilmister R and Treeby M. 2017. Multi-seasonal effects of warming and elevated $\mathrm{CO}_{2}$ on the physiology, growth and production of mature, field grown, Shiraz grapevines. OENO One 51:127-132.

Faralli M, Grove IG, Hare MC, Kettlewell PS and Fiorani F. 2017. Rising $\mathrm{CO}_{2}$ from historical concentrations enhances the physiological performance of Brassica napus seedlings under optimal water supply but not under reduced water availability. Plant Cell Environ 40:317-25.

Fraga H, De Cortázar Atauri IG, Malheiro AC and Santos JA. 2016. Modelling climate change impacts on viticultural yield, phenology and stress conditions in Europe. Glob Chang Biol 22:3774-3788.

Francis L. 2012. Fermentation-derived aroma compounds and grapederived monoterpenes. Appl Microbiol Biotechnol 96:601-618.

Galat Giorgi E, Sadras VO, Keller M and Perez Peña J. 2019. Interactive effects of high temperature and water deficit on Malbec grapevines. Aust J Grape Wine Res 25:345-356.

Goicoechea N, Jiménez L, Prieto E, Gogorcena Y, Pascual I, Irigoyen JJ and Antolín MC. 2021. Assessment of nutritional and quality properties of leaves and musts in three local Spanish grapevine varieties undergoing controlled climate change scenarios. Plants 10:1198.

Gonçalves B, Falco V, Moutinho-Pereira J, Bacelar E, Peixoto F and Correia C. 2008. Effects of elevated $\mathrm{CO}_{2}$ on grapevine (Vitis vinifera L.): volatile composition, phenolic content, and in vitro antioxidant activity of red wine. J Agric Food Chem 57:265-273.

Gray SB et al. 2016. Intensifying drought eliminates the expected benefits of elevated carbon dioxide for soybean. Nature Plants 9:1-8.

Hao Z, Fayolle L, van Tuinen D, Chatagnier O, Li X, Gianinazzi S and Gianinazzi-Pearson V. 2012. Local and systemic mycorrhizainduced protection against the ectoparasitic nematode Xiphinema index involves priming of defence gene responses in grapevine. $\mathrm{J}$ Exp Bot 63:3657-3672.

Hunter MD. 2001. Effects of elevated atmospheric carbon dioxide on insect-plant interactions. Agric For Entomol 3:153-159.

Iltis C, Martel G, Thiéry D, Moreau J and Louâpre P. 2018. When warmer means weaker: High temperatures reduce behavioural and immune defenses of the larvae of a major grapevine pest. J Pest Sci 91:1315-1326.

Intergovernmental Panel on Climate Change (IPCC). 2014. Climate Change 2014: Synthesis Report. Contribution of Working Groups I, II and III to the Fifth Assessment Report of the Intergovernmental 
Panel on Climate Change. Pachauri R and Meyer L (eds.). Geneva, Switzerland.

Jones GV. 2013. Winegrape phenology. In Phenology: An Integrative Environmental Science. Schwartz M (ed.), pp. 563-584. Springer, Dordrecht.

Jones GV. 2021. Wine production and climate change. In World Scientific Encyclopedia of Climate Change: Case Studies of Climate Risk, Action, and Opportunity. Vol. 2. Dash JW (ed.), pp. 177-184. World Scientific Publishing Co. Pte. Ltd., Singapore.

Jones GV, White MA, Cooper OR and Storchmann K. 2005. Climate change and global wine quality. Clim Change 73:319-343.

Kizildeniz T, Irigoyen JJ, Pascual I and Morales F. 2018. Simulating the impact of climate change (elevated $\mathrm{CO}_{2}$ and temperature, and water deficit) on the growth of red and white Tempranillo grapevine in three consecutive growing seasons (2013-2015). Agr Water Manage 202:220-230

Kizildeniz T, Pascual I, Irigoyen JJ and Morales F. 2021. Future $\mathrm{CO}_{2}$, warming and water deficit impact white and red Tempranillo grapevine: Photosynthetic acclimation to elevated $\mathrm{CO}_{2}$ and biomass allocation. Physiol Plant 172:1779-1794.

Kliewer WM and Smart RE. 1989. Canopy manipulation for optimizing vine microclimate, crop yield and composition of grapes. In Manipulation of Fruiting. Wright CJ (ed.), pp. 275-291. Butterworth \& Co. Publishers, London.

Leakey ADB, Ainsworth EA, Bernacchi CJ, Rogers A, Long SP and Ort DR. 2009. Elevated $\mathrm{CO}_{2}$ effects on plant carbon, nitrogen, and water relations: Six important lessons from FACE. J Exp Bot 60:2859-2876.

Lebon G, Wojnarowiez G, Holzapfel B, Fontaine F, Vaillant-Gaveau N and Clément C. 2008. Sugars and flowering in the grapevine (Vitis vinifera L.). J Exp Bot 59:2565-2578.

Li YM, Forney C, Bondada B, Leng F and Xie ZS. 2021. The molecular regulation of carbon sink strength in grapevine (Vitis vinifera L.). Front Plant Sci 11:2149.

Lobell DB, Field CB, Cahill KN and Bonfils C. 2006. Impacts of future climate change on California perennial crop yields: Model projections with climate and crop uncertainties. Agr Forest Meteorol 141:208-218.

Long SP and Drake BG. 1992. Photosynthetic $\mathrm{CO}_{2}$ assimilation and rising atmospheric $\mathrm{CO}_{2}$ concentrations. In Crop Photosynthesis: Spatial and Temporal Determinants. Baker NR and Thomas H (eds.), pp. 69-107. Elsevier Science Publishers.

Luo HB, Ma L, Xi HF, Duan W, Li SH, Loescher W, Wang JF and Wang LJ. 2011. Photosynthetic responses to heat treatments at different temperatures and following recovery in grapevine (Vitis amurensis L.) leaves. PLoS ONE:6:e23033.

Luo Y, Field CB and Mooney HA. 1994. Predicting responses of photosynthesis and root fraction to elevated $\mathrm{CO}_{2}$ : Interactions among carbon, nitrogen and growth. Plant Cell Environ 17:1195-1204.

Mariani L, Cola G, Maghradze D, Failla O and Zavatti F. 2018. Influence of climate cycles on grapevine domestication and ancient migrations in Eurasia. Sci Total Enviro 635:1240-1254.

Martínez de Toda Fernández F, Sancha González JC, Zheng W and Balda Manzanos P. 2014. Leaf area reduction by trimming, a growing technique to restore the anthocyanins: Sugars ratio decoupled by the warming climate. Vitis 53:189-192.

Martínez-Lüscher J, Morales F, Sánchez-Díaz M, Delrot S, Aguirreolea J, Gomès E and Pascual I. 2015. Climate change conditions (elevated $\mathrm{CO}_{2}$ and temperature) and UV-B radiation affect grapevine (Vitis vinifera $\mathrm{cv}$. Tempranillo) leaf carbon assimilation, altering fruit ripening rates. Plant Sci 236:168-176.

Martínez-Lüscher J et al. 2016a. Sensitivity of grapevine phenology to water availability, temperature and $\mathrm{CO}_{2}$ concentration. Front Enviro Science 4:48.
Martínez-Lüscher J, Sánchez-Díaz M, Delrot S, Aguirreolea J, Pascual I and Gomès E. 2016b. Ultraviolet-B alleviates the uncoupling effect of elevated $\mathrm{CO}_{2}$ and increased temperature on grape berry (Vitis vinifera cv. Tempranillo) anthocyanin and sugar accumulation. Aust J Grape Wine Res 22:87-95.

Medrano H, Tomás M, Martorell S, Flexas J, Hernández E, Rosselló J, Pou A, Escalona JM and Bota J. 2015. From leaf to whole-plant water use efficiency (WUE) in complex canopies: Limitations of leaf WUE as a selection target. Crop J 3:220-228.

Mondani L, Palumbo R, Tsitsigiannis D, Perdikis D, Mazzoni E and Battilani P. 2020. Pest management and ochratoxin A contamination in grapes: A review. Toxins 12:303.

Morales-Castilla I, de Cortázar-Atauri IG, Cook BI, Lacombe T, Parker A, van Leeuwen C, Nicholas KA and Wolkovich EM. 2020. Diversity buffers winegrowing regions from climate change losses. Proc Natl Acad Sci USA 117:2864-2869.

Mosedale JR, Abernethy KE, Smart RE, Wilson RJ and Maclean IMD. 2016. Climate change impacts and adaptive strategies: Lessons from the grapevine. Glob Chang Biol 22:3814-3828.

Moutinho-Pereira J, Gonçalves B, Bacelar E, Boaventura Cunha J, Countinho J and Correia CM. 2009. Effects of elevated $\mathrm{CO}_{2}$ on grapevine (Vitis vinifera L.): Physiological and yield attributes. Vitis 48:159-165.

Ollat N, van Leeuwen C, de Cortazar Atauri IG and Touzard JM. 2017. The challenging issue of climate change for sustainable grape and wine production. OENO One 51:59-60.

Owens CL. 2008. Grapes. In Temperate Fruit Crop Breeding. Hancock JF (ed.), pp. 197-233. Springer, Dordrecht.

Parker AK. 2012. Modelling phenology and maturation of the grapevine Vitis vinifera L.: Varietal differences and the role of leaf area to fruit weight ratio manipulations. Thesis, Lincoln University, NZ.

Parker AK, Hofmann RW, van Leeuwen C, McLachlan ARG and Trought MCT. 2014. Leaf area to fruit mass ratio determines the time of veraison in Sauvignon Blanc and Pinot Noir grapevines. Aust J Grape Wine Res 20:422-431.

Parker LE, McElrone AJ, Ostoja SM and Forrestel EJ. 2020. Extreme heat effects on perennial crops and strategies for sustaining future production. Plant Sci 295:110397.

Paudel I, Halpern M, Wagner Y, Raveh E, Yermiyahu U, Hoch G and Klein T. 2018. Elevated $\mathrm{CO}_{2}$ compensates for drought effects in lemon saplings via stomatal downregulation, increased soil moisture, and increased wood carbon storage. Environ Exp Bot 148:117-127.

Pearson PN and Palmer MR. 2000. Atmospheric carbon dioxide concentrations over the past 60 million years. Nature 406:695-699.

Pertot I et al. 2017. A critical review of plant protection tools for reducing pesticide use on grapevine and new perspectives for the implementation of IPM in viticulture. Crop Prot 97:70-84.

Poni S, Casalini L, Bernizzoni F, Civardi S and Intrieri C. 2006. Effects of early defoliation on shoot photosynthesis, yield components, and grape composition. Am J Enol Vitic 57:397-407.

Pons A, Allamy L, Schüttler A, Rauhut D, Thibon C and Darriet P. 2017. What is the expected impact of climate change on wine aroma compounds and their precursors in grape? OENO One 51:141-146.

Ponti L, Gutierrez AP, Boggia A and Neteler M. 2018. Analysis of grape production in the face of climate change. Climate 6:20.

Pugliese M, Gullino ML and Garibaldil A. 2010. Effects of elevated $\mathrm{CO}_{2}$ and temperature on interactions of grapevine and powdery mildew: First results under phytotron conditions. J Plant Dis Prot 117:9-14.

Rangel da Silva J, Patterson AE, Rodriguez WP, Campostrini E and Griffin KL. 2017. Photosynthetic acclimation to $\mathrm{CO}_{2}$ combined with partial root-zone drying results in improved water use efficiency, 
drought tolerance and leaf carbon balance of grapevines (Vitis labrusca). Environ Exp Bot 134:82-95.

Reddy LS, Reddy AGK, Vanaja M, Maruthi V and Latha KV. 2018. Effect of elevated $\mathrm{CO}_{2}$ and temperature on root length and root diameter of cuttings of grape varieties under face and fate facilities. Plant Arch 18:661-664.

Reineke A and Selim M. 2019. Elevated atmospheric $\mathrm{CO}_{2}$ concentrations alter grapevine (Vitis vinifera) systemic transcriptional response to European grapevine moth (Lobesia botrana) herbivory. Sci Rep 9:2995.

Rogiers SY, Hardie WJ and Smith JP. 2011. Stomatal density of grapevine leaves (Vitis vinifera L.) responds to soil temperature and atmospheric carbon dioxide. Aust J Grape Wine Res 17:147-152.

Salazar-Parra CS, Aguirreolea J, Sánchez-Díaz M, Irigoyen JJ and Morales F. 2010. Effects of climate change scenarios on Tempranillo grapevine (Vitis vinifera L.) ripening: Response to a combination of elevated $\mathrm{CO}_{2}$ and temperature, and moderate drought. Plant Soil 337:179-191.

Salazar-Parra C, Aguirreolea J, Sánchez-Diaz M, Irigoyen JJ and Morales F. 2012. Photosynthetic response of Tempranillo grapevine to climate change scenarios. Annals Appl Bio 161:277-292.

Salazar-Parra C, Aranjuelo I, Pascual I, Erice G, Sanz-Sáez Á, Aguirreolea J, Sánchez-Diaz M, Irigoyen JJ and Morales F. 2015. Carbon balance, partitioning and photosynthetic acclimation in fruit-bearing grapevine (Vitis vinifera L. cv. Tempranillo) grown under simulated climate change (elevated $\mathrm{CO}_{2}$, elevated temperature, and moderate drought) scenarios in temperature gradient greenhouses. J Plant Physiol 174:97-109.

Santos JA et al. 2020. A review of the potential climate change impacts and adaptation options for European viticulture. Appl Sci 10:3092.

Scholasch T and Rienth M. 2019. Review of water deficit mediated changes in vine and berry physiology; Consequences for the optimization of irrigation strategies. OENO One 53:423-444.

Schultz HR and Stoll M. 2010. Some critical issues in environmental physiology of grapevines: future challenges and current limitations. Aust J Grape Wine Res 16:4-24.

Schulze-Sylvester M and Reineke A. 2019. Elevated $\mathrm{CO}_{2}$ levels impact fitness traits of vine mealybug Planococcus ficus Signoret, but not its parasitoid Leptomastix dactylopii Howard. Agronomy 9:326.

Schulze-Sylvester M, Corronca JA and Paris CI. 2021. Vine mealybugs disrupt biomass allocation in grapevine. OENO One 55:93-103.

Springer CJ and Ward JK. 2007. Flowering time and elevated atmospheric $\mathrm{CO}_{2}$. New Phytol 176:243-255.

Terral JF et al. 2010. Evolution and history of grapevine (Vitis vinifera) under domestication: New morphometric perspectives to understand seed domestication syndrome and reveal origins of ancient European cultivars. Ann Bot 105:443-455.

Teslić N, Zinzani G, Parpinello GP and Versari A. 2018. Climate change trends, grape production, and potential alcohol concentration in wine from the "Romagna Sangiovese" appellation area (Italy). Theor Appl Climat 131:793-803.
Thakur MP et al. 2019. Soil microbial, nematode, and enzymatic responses to elevated $\mathrm{CO}_{2}, \mathrm{~N}$ fertilization, warming, and reduced precipitation. Soil Bio Biochem 135:184-193.

Torres N, Antolín MC and Goicoechea N. 2018. Arbuscular mycorrhizal symbiosis as a promising resource for improving berry quality in grapevines under changing environments. Front Plant Sci 9:897.

Ubeda C, Hornedo-Ortega R, Cerezo AB, Garcia-Parrilla MC and Troncoso AM. 2020. Chemical hazards in grapes and wine, climate change and challenges to face. Food Chem 314:126222.

Ugaglia AA, Cardebat JM and Jiao L. 2019. The French wine industry. In The Palgrave Handbook of Wine Industry Economics. Ugaglia AA et al. (eds.), pp. 17-46. Palgrave Macmillan, Cham, Switzerland.

van Leeuwen C and Darriet P. 2016. The impact of climate change on viticulture and wine quality. J Wine Econ 11:150-167.

VanderWeide J, Gottschalk C, Schultze SR, Nasrollahiazar E, Poni S and Sabbatini P. 2021. Impacts of pre-bloom leaf removal on wine grape production and quality parameters: A systematic review and meta-analysis. Front Plant Sci 11:2245.

Vasconcelos MC, Greven M, Winefield CS, Trought MCT and Raw V. 2009. The flowering process of Vitis vinifera: A review. Am J Enol Vitic 60:411-434.

Venios X, Korkas E, Nisiotou A and Banilas G. 2020. Grapevine responses to heat stress and global warming. Plants 9:1754.

Vivier MA and Pretorius IS. 2002. Genetically tailored grapevines for the wine industry. Trends Biotechnol 20:472-478.

Weiss E, Kislev ME, Simchoni O and Nadel D. 2004. Small-grained wild grasses as staple food at the 23,000-year-old site of Ohalo II, Israel. Econ Bot 58:S125-S134.

White MA, Diffenbaugh NS, Jones GV, Pal JS and Giorgi F. 2006. Extreme heat reduces and shifts United States premium wine production in the 21st century. Proc Natl Acad Sci USA 103:11217-11222.

Wohlfahrt Y, Tittmann S and Stoll M. 2017. Physiological and yield performance of Vitis vinifera L. cvs. (Riesling and Cabernet Sauvignon) under Free Air Carbon Dioxide Enrichment (FACE). In Proceedings of the GiESCO 20th International Meeting 2017, Mendoza, Argentina.

Wohlfahrt Y, Smith JP, Tittmann S, Honermeier B and Stoll M. 2018. Primary productivity and physiological responses of Vitis vinifera L. cvs. under Free Air Carbon Dioxide Enrichment (FACE). Eur J Agron 101:149-162.

Wolkovich EM, de Cortázar-Atauri IG, Morales-Castilla I, Nicholas KA and Lacombe T. 2018. From Pinot to Xinomavro in the world's future wine-growing regions. Nat Clim Change 8:29-37.

Zufferey V, Murisier F, Vivin P, Belcher S, Lorenzini F, Spring JL and Viret O. 2012. Carbohydrate reserves in grapevine (Vitis vinifera L. 'Chasselas'): The influence of the leaf to fruit ratio. Vitis 51:103-110. 